\title{
Classification of immature mosquito species according to characteristics of the larval habitat in the subtropical province of Chaco, Argentina
}

\author{
Marina Stein ${ }^{1 /+}$, Francisco Ludueña-Almeida², Juana Alicia Willener ${ }^{1}$, Walter Ricardo Almirón² \\ ${ }^{1}$ Instituto de Medicina Regional, Universidad Nacional del Nordeste, Av. Las Heras 727, 3500 Resistencia, Chaco, Argentina \\ ${ }^{2}$ Centro de Investigaciones Entomológicas, Facultad de Ciencias Exactas, Físicas y Naturales, Universidad Nacional de Córdoba, Córdoba, Argentina
}

To classify mosquito species based on common features of their habitats, samples were obtained fortnightly between June 2001-October 2003 in the subtropical province of Chaco, Argentina. Data on the type of larval habitat, nature of the habitat (artificial or natural), size, depth, location related to sunlight, distance to the neighbouring houses, type of substrate, organic material, vegetation and algae type and their presence were collected. Data on the permanence, temperature, $p H$, turbidity, colour, odour and movement of the larval habitat's water were also collected. From the cluster analysis, three groups of species associated by their degree of habitat similarity were obtained and are listed below. Group 1 consisted of Aedes aegypti. Group 2 consisted of Culex imitator, Culex davisi, Wyeomyia muehlensi and Toxorhynchites haemorrhoidalis separatus. Within group 3, two subgroups are distinguished: A (Psorophora ferox, Psorophora cyanescens, Psorophora varinervis, Psorophora confinnis, Psorophora cingulata, Ochlerotatus hastatusoligopistus, Ochlerotatus serratus, Ochlerotatus scapularis, Culex intrincatus, Culex quinquefasciatus, Culex pilosus, Ochlerotatus albifasciatus, Culex bidens) and B (Culex maxi, Culex eduardoi, Culex chidesteri, Uranotaenia lowii, Uranotaenia pulcherrima, Anopheles neomaculipalpus, Anopheles triannulatus, Anopheles albitarsis, Uranotaenia apicalis, Mansonia humeralis and Aedeomyia squamipennis). Principal component analysis indicates that the size of the larval habitats and the presence of aquatic vegetation are the main characteristics that explain the variation among different species. In contrast, water permanence is second in importance. Water temperature, $\mathrm{pH}$ and the type of larval habitat are less important in explaining the clustering of species.

Key words: Culicidae - larval habitats - subtropical - Chaco - Argentina

The study of larval habitats and their physicochemical characteristics contributes information about the distribution and abundance of adult mosquito populations (Forattini 1962) and helps to develop appropriate larval control strategies. At the same time, the classification of mosquito species on the basis of common features of their habitats increases the knowledge about mosquito biology during the immature stages. Several investigations have been conducted to characterise mosquito larval habitats and to cluster the species based on common habitats for development. Forattini (1962) distinguished habitats according to the diapause period required for some mosquito species, making the first differentiation based on the permanence of water in the breeding sites. Classifying water collections as permanent or temporary is useful because mosquito species in the genera Aedes and Psorophora require a period of diapause before hatching. In contrast, the Mansonia and Coquillettidia genera are always associated with aquatic vegetation because larvae and pupae obtain oxygen from plant aerenchyma, which are always found in permanent water habitats, such as lagoons (Forattini 1962, Garcia-Ávila 1977).

\footnotetext{
Financial support: Secretaría General de Ciencia y Técnica/UNNE (PI-538) + Corresponding author: marinastein@yahoo.com.ar Received 21 October 2010

Accepted 24 March 2011
}

Rejmankova et al. (1991, 1992) classified the larval habitat of Anopheles species on the basis of aquatic vegetation. Rubio-Palis et al. (2005) studied the physicochemical and biotic features of anopheline larval habitats and concluded that lagoons are the most favourable habitats for immature Anopheles development in Venezuela.

Among the studies on larval habitat conducted in Argentina, Torales et al. (1972) studied some of the physicochemical characteristics of water contained in bromeliads in province of Corrientes. The water chemistry of ditches in province of Buenos Aires and the anopheline larval habitats were studied (Campos et al. 1993, Campos 1997). Almirón and Brewer (1996) characterised a variety of habitats where immature mosquitoes were collected in province of Cordoba on the basis of their physiognomic, physicochemical, biological and morphometric features and classified the mosquito species according to the similarity of their habitats. This study allowed the authors to group different genera and species possessing very different biological characteristics using data of biological and epidemiological interest.

Other studies conducted in province of Chaco (Argentina) documented the circulation of arbovirus transmitted by mosquitoes (Mitchell et al. 1985, 1987, Pisano et al. 2010). However, no systematic studies of mosquito larval habitats have been conducted in this province. Therefore, the objective of this paper was to describe the characteristics of larval habitats where immature mosquitoes were collected and to classify mosquito species on the basis of common features of their habitats, thereby contributing to the body of knowledge about the biology of mosquitoes at immature stages. 


\section{MATERIALS AND METHODS}

Study area - Chaco is located between $28^{\circ}-25^{\circ} 39^{\prime} \mathrm{S}$ $61^{\circ} 42^{\prime}-62^{\circ} 20^{\prime} \mathrm{W}$. It is characterised by a very large plain with smooth slopes towards the southeast. The climate is subtropical with a dry season. It is part of an extensive phytogeographic area, commonly called Parque Chaqueño, where vegetation has a polymorphic appearance and consists of xeric forests, shrubs and herbaceous steppes, savannas, palm groves and grasslands. Phytogeographically, it is divided into two regions: eastern and western woodland (Bruniard 1978). The eastern woodland, where this study was conducted, is within a flood plain with imperfect or poor drainage. The soil permeability is moderately slow, which allows the formation of flooding areas (Bruniard 1978).

The presence of forests (which can exceed heights of $25 \mathrm{~m}$ ), palms, riparian forests, canyons, swamps, marshes and areas covered with herbaceous vegetation is also characteristic of the eastern woodland. The climax community is composed of Schinopsis balansae Engl. forest and the subclimax community is formed by riparian forests. In flooded areas, palm groves of Copernicia alba Morong and Elionurus muticus (Spreng.) Kunze develop and an extensive grassland and riparian forest are present at the higher elevations. Forest is the dominant form of associated vegetation. The forest grove with lianas and bromeliads is almost impenetrable. Aquatic vegetation is found in estuaries and lagoons, which are densely covered with floating species and some radicant hydrophyte species. The margins of water bodies are covered by Cyperaceae and grass (Cabrera 1994). Bromeliads can be both terrestrial and epiphytic, although the latter is not very abundant.

The mean annual temperature is $23^{\circ} \mathrm{C}$ and the mean rainfall is $1280 \mathrm{~mm}$. In the summer, the mean temperature is $27^{\circ} \mathrm{C}$, with an absolute maximum that can exceed $43^{\circ} \mathrm{C}$. The mean temperature in winter is $15^{\circ} \mathrm{C}$. The rainy season is between November-April, with peaks of rainfall in spring (September-October) and autumn (MarchApril) (Bruniard 1978).

Sampling of larval habitats - To achieve a greater diversity of larval habitats, three environments that showed different degrees of anthropic modification were selected: (i) an urban environment (in the city of Resistencia, $27^{\circ} 30^{\prime} \mathrm{S} 59^{\circ} \mathrm{W}$ ), (ii) a scarcely modified natural environment (located $10 \mathrm{~km}$ from Resistencia, $27^{\circ} 26^{\prime} \mathrm{S} 58^{\circ} 55^{\prime} \mathrm{W}$ ) and (iii) a wild environment with no modification corresponding to a patch of original wood (located at km 1031 of Route $11,27^{\circ} 10^{\prime}$ 'S $58^{\circ} 58^{\prime} \mathrm{W}$ ).

The habitats were categorised according to the following definitions: bromeliad: axils of Bromeliaceae leaves, Aechmea distichantha Lem., both terrestrial and epiphytic varieties; lagoon: with floating and emergent aquatic vegetation; pool: natural, shallow and temporary habitat with or without grass; ditch: narrow deep channel of drains in the ground; artificial container: man-made receptacles that can collect water; deep pool: depression in the ground made through the action of man or animals. According to Forattini (1962), the last three are considered artificial larval habitats. Artificial containers and ditches were only present in the urban environment.
Larvae and pupae were collected fortnightly from 41 larval habitats ( 3 deep pools, 2 lagoons, 11 terrestrial bromeliads and 1 epiphytic bromeliad, 16 pools, 3 artificial containers and 5 ditches) between June 2001-October 2003. For each immature stage habitat, the following characteristics were recorded and used for the analysis: habitat natural or artificial, the type, size, water depth, distance to the nearest house, water permanence, turbidity, water temperature, colour, odour and $\mathrm{pH}$, substrate, presence of decaying organic matter, presence of aquatic vegetation, type of aquatic vegetation, presence of filamentous algae, location in relation to sunlight and presence of grass (Table).

Samples were collected using a $500 \mathrm{~mL}$ dipper and the number of mosquito immature stage larvae collected in 20 dips was recorded; a suction bottle was used for bromeliad axils and all water present was suctioned. Specimen identification was based on fourth instar larvae and/or adults, using characteristics outlined in Lane (1953), Ronderos and Bachman (1962), Forattini (1962, 1965a, b), Bram (1967), Darsie (1985), as well as Consoli and Lourenço-

\section{TABLE}

Environmental variables used in the cluster analysis of larval habitats

Environmental variables

Type of larval habitat (epiphyte and terrestrial bromeliad, lagoon, pool, deep pool, ditch, and artificial container)

Natural or artificial

Water temperature (mean) registered with bulb thermometer Size of larval habitat (m)

Width of larval habitat (m)

Depth (m)

Water permanence (permanent: when water was present through the study; semipermanent: when water was still over one month in the habitat; temporary: when water was still less than a week in the habitat)

Turbidity (visually estimated, considering a sample turbid when the bottom of the white dipper could not be seen)

Colour (visually estimated)

Odour (with or without unpleased odour)

$\mathrm{pH}$ (recorded with a digital device)

Muddy substrate

Sandy substrate

Decaying organic matter (presence or absence)

Aquatic vegetation (presence or absence)

Emergent aquatic vegetation (presence or absence)

Floating aquatic vegetation (presence or absence)

Submerged aquatic vegetation (presence or absence)

Type of aquatic vegetation (grasses, grasses and herbaceus)

Filamentous algae (presence or absence)

Location in relation to sunlight (sunlight, partial shade or deep shade)

Grass (presence or absence)

Distance to the nearest house 
de-Oliveira (1994). Larvae from the first to third instar were reared to the fourth instar and pupae up to adults were reared for identification (Belkin et al. 1967).

Specimens were deposited in the entomological collections of the Instituto de Medicina Regional, Universidad Nacional del Nordeste (Chaco) and the Centro de Investigaciones Entomológicas, Edificio de Investigaciones Biológicas y Tecnológicas, Facultad de Ciencias Exactas, Físicas y Naturales, Universidad Nacional de Córdoba (Córdoba).

Data analysis - Cluster analysis was performed to classify the mosquito species collected based on 23 larval habitat characteristics (Table). Data were analysed according to the method proposed by Crisci and Lopez Armengol (1983). The operative taxonomic units (OTUs) chosen were the species collected. For continuous environmental variables (size, distance from the habitat to the nearest house, $\mathrm{pH}$ and depth) the arithmetic mean was calculated. The dispersion of quantitative variables and their corresponding ranges of variation are shown in Supplementary data. Categorical variables (natural or artificial, type, shade, water permanence, turbidity and vegetation) were codified 1/0 (present/absent). A basic matrix of data was developed based on the codified data, consisting of 30 rows for the mosquito species and $30 \mathrm{col}-$ umns for all of the characteristics $(22+7$ types of larval habitat) (Table). Cluster analysis was based on the taxonomic distance coefficient (Crisci \& Lopez Armengol 1983). The coefficients obtained were used to develop the similarity matrix. Cluster analysis was used to group the OTUs by similarity. The unweighted pair group method using arithmetic averages was applied as a linkage technique. The clusters were represented by a phenogram.

Principal component analysis (PCA) was used to examine the relationship among all species based on their larval habitat similarity, allowing us to identify which variables have more importance for the grouping of species (Crisci \& Lopez Armengol 1983). The software INFOSTAT (2002) was used for the analysis.

\section{RESULTS}

A total of 30 mosquito species were collected in the studied area and these species were clustered into three groups based on the analysis of the habitat characteristics. Species collected from one type of habitat, such as species exclusively from bromeliads (Culex imitator Theobald, Culex davisi Kumm, Wyeomyia muehlensi Petrocchi, Toxorhynchites haemorrhoidalis separatus Arribalzaga) formed one group. Species from artificial containers (Aedes aegypti Linnaeus) were a second group. Finally, species collected from different larval habitats on the ground (belonging to the Aedeomyia, Anopheles, Culex, Mansonia, Ochlerotatus, Psorophora and Uranotaenia genera) were grouped together (Fig. 1). The main characteristics that defined the phenogram obtained were type and size of larval habitats, water permanence and the associated vegetation. According to the PCA, the first two components explain 54\% of the total variation observed among the different mosquito species. The characteristics that most contribute to an explanation for the variation in principal component 1 are size (length and width), aquatic vegetation and colour. These characteristics separated those species found in small larval habitats (artificial containers or bromeliads) from those species found in large larval habitats, such as lagoons, or in the presence of aquatic vegetation. Within a set of intermediate-sized habitats there are species collected mainly from pools (Fig. 2). The permanence of water, the presence of grass and the distance to the nearest houses are the most important characteristics for explaining variation in the second component, clustering the species found in temporary habitats such as pools, deep pools and artificial containers with those found in permanent habitats such as lagoons and bromeliad axils (Fig. 2). The PCA also showed a trend of variation or ecological gradient determined by the water permanence and aquatic vegetation variables. So, the species of group 3, found in temporary pools without aquatic

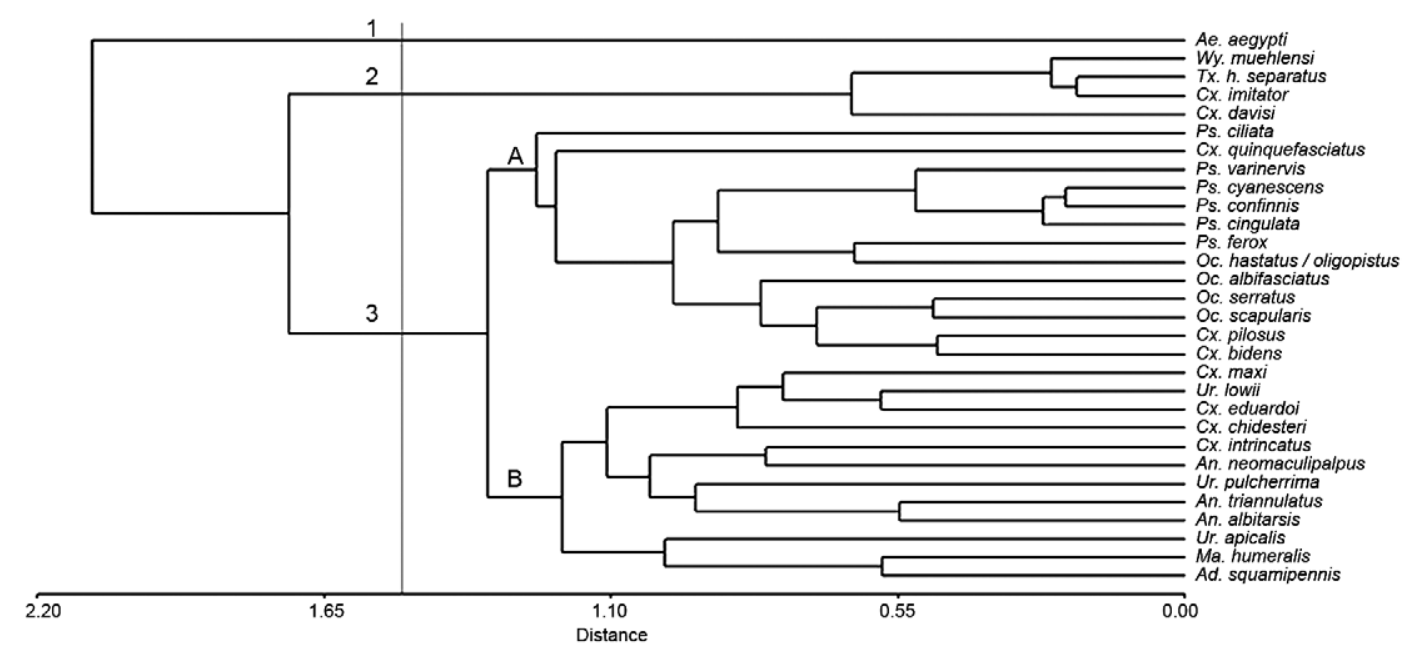

Fig. 1: phenogram of 30 operative taxonomic units (species) resulting from the cluster analysis. Numbers 1-3 indicate the clusters. The scale $-0.10-2.16$ indicates the range of the distance coefficients obtained. 
vegetation, are clustered in one extreme of the gradient and on the other extreme are grouped the species collected from lagoons, with aquatic vegetation and water permanence observed throughout the study (Fig. 2).

Water temperature, $\mathrm{pH}$ and the type of larval habitat contribute less towards explaining the clustering of species. Species found in bromeliads are negatively associated with $\mathrm{pH}$, while those species found in ditches are positively associated with $\mathrm{pH}$ (Fig. 2).

During the dry season, larval habitats are restricted almost exclusively to lagoons, bromeliads and ditches with aquatic vegetation. However, during the wet season large areas with grasses are flooded, resulting in several pools and other sites filled with rain water that are available for mosquito breeding. In all larval habitats, the water was stagnant, thus this characteristic was not taken into account for the cluster analysis.

The larval-habitat characteristics of each species cluster - Ae. aegypti (group 1) was collected from artificial containers with clean or turbid water in the presence of fallen leaves that produced an unpleasant odour. The containers were mainly of small size, always near to houses, located in partial shade or sunlight and contained water with a basic pH (Supplementary data). These mosquitoes were collected from a discarded bathtub and from the iron top of a sanitary drainage apparatus that was still operating.

Species from group 2 (Cux. imitator, Cux. davisi, Wy. muehlensi and Tx. haemorrhoidalis separatus) were found exclusively in bromeliad leaf axils (A. distichantha), both terrestrial and epiphytic. The species were found both close to and far away from houses, either in partial shade or sunlight. Other recorded characteristics, such as $\mathrm{pH}$, water temperature and water colour, showed a wide range of variability (Supplementary data).

Group 3 species were collected from habitats located on the ground (lagoons, ditches, pools and deep pools). The type of habitat, water permanence and aquatic vegetation further define two subgroups (A and B) (Fig. 1). The species of subgroup A were collected mainly in natural, temporary ground pools, located either near to or far away from the houses, exposed to sunlight, varying from small to large in size and with clear or turbid water (Supplementary data). Some of the subgroup A species were also collected from lagoons, ditches and deep pools (Supplementary data). Most of the habitat characteristics were shared by these species, but variations in the recorded water temperature and $\mathrm{pH}$ allowed them to be separated.

Ochlerotatus and Psorophora species were found in water bodies possessed a water temperature range that was higher than those from which Culex species were collected, but the $\mathrm{pH}$ range was lower (Supplementary data). Ochlerotatus albifasciatus (Macquart) and Culex bidens Dyar form a nucleus that can be distinguished by the permanence of the water and exposure to the sun in the larval habitats from which they were collected. Oc. albifasciatus was collected from temporary pools that had partial shade or sunlight. In contrast, Cux. bidens was collected from both deep shade and sunlight and from temporary or permanent water (Supplementary data).

The nucleus Culex pilosus (Dyar and Knab)-Culex quinquefasciatus Say is distinguished by the nature of the larval habitat. Cux. pilosus was mainly collected from natural habitats, while Cux. quinquefasciatus was collected from artificial ones (Supplementary data).

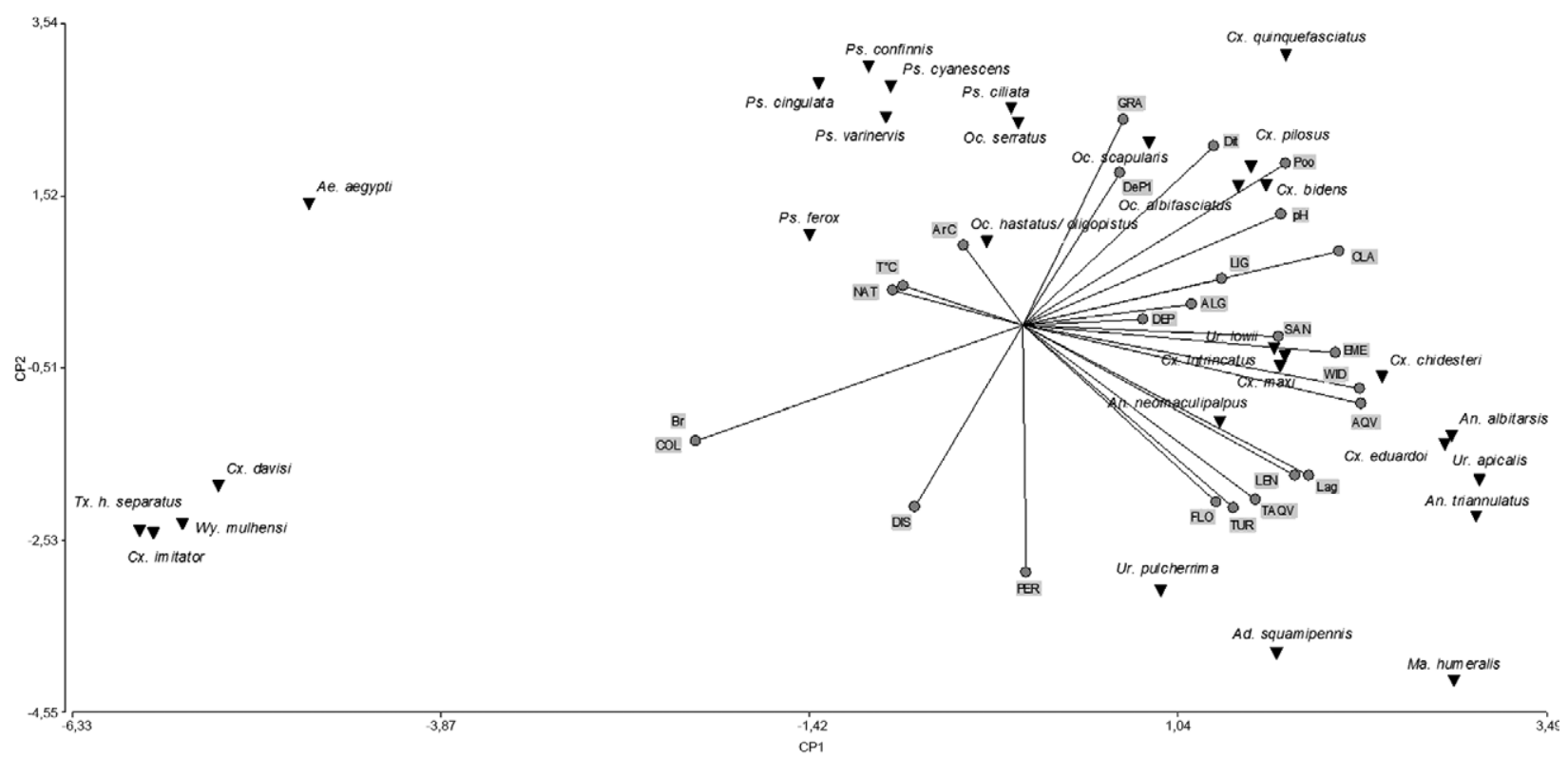

Fig. 2: location of species (operative taxonomic units) in the space determinated from 1 and 2 principal components. Triangles are species collected in the province of Chaco, Argentina. ALG: algae; AQV: aquatic vegetation; ArC: artificial container; Br: bromeliad; CLA: claw substrate; COL: colour; DeP1: deep pool; DIS: distance from breeding sites to the nearest house; Dit: ditch; EME: emergent aquatic vegetation; FLO: floating aquatic vegetation; GRA: grasses; Lag: lagoon; LIG: light, pH; LON: long; NAT: nature; PER: water permanence; Poo: pool; SAN: sandy substrate; TAQV: type of aquatic vegetation; TUR: turbidity; $\mathrm{T}^{\circ} \mathrm{C}$ : temperature; WD: water deep; WID: width. 
Both species can be separated from the others because they were collected in the presence of filamentous algae. Cux. quinquefasciatus was found mainly in habitats with turbid water, an unpleasant odour and the widest average basic-pH range (Supplementary data).

Species of group 3 subgroup B were more frequently found in natural habitats $(>50 \%)$, mainly represented by pools and lagoons, but they were also collected from ditches (26-41\%). The mean water temperatures in which species of subgroup B were collected were lower than those where the species from subgroup A were found (Supplementary data). Habitats were located in partial light, deep shade or sunlight, both close to and far away from houses, with clear or turbid water, with or without organic matter, with or without unpleasant odour and the larval-habitat size varied from small ( $<3 \mathrm{~m}$ length)-large (>10 $\mathrm{m}$ length). The presence of aquatic vegetation and the water permanence in larval habitats where these species were found also distinguished this subgroup. Culex maxi Dyar can be separated from the other species of the subgroup because it was collected in habitats with or without grass. The other species were always collected from habitats with grass (present in pools): floating hydrophytes, such as Pistia stratiotes L. and Salvinia minima Baker, emerging hydrophytes, such as Enydra anagallis Gardner and Alternanthera philoxeroides (Mart.) Griseb, present in lagoons, and Ludwigia sp. L., Sagittaria sp. L. and Polygonum sp. L., present in ditches.

Uranotaenia pulcherrima Arribalzaga can be separated from the other species because it was always found far away from houses (Supplementary data).

The nucleus composed of Aedeomyia squamipennis Arribalzaga and Mansonia humeralis Dyar and Knab can be separated from the other species by the type of habitat (they were collected exclusively from lagoons), the substrate type, the exposure to sunlight, the presence of algae and the higher mean water temperature (Supplementary data).

\section{DISCUSSION}

In Argentina, since the re-introduction of Ae. aegypti in 1987, this species has been detected almost exclusively in artificial containers located in urban areas (Olmedo et al. 1991, Schweigmann et al. 1997, Almirón \& LudueñaAlmeida 1998, Augier 1998, Borda et al. 1999, Lestani et al. 2002, Stein \& Oria 2002, Stein et al. 2002, 2007). However, the National Coordination of Vector Control (Ministry of Health of Argentina) has reported finding larvae in the axils of banana leaves in the province of Misiones and Mangudo et al. (2010) collected immature stage larvae from tree holes in the province of Salta. Ae. aegypti has been found in water with $\mathrm{pH}$ values between 5.8-8.6 (Christophers 1960). In terms of habitat size, Ae. aegypti seems to prefer both small and medium habitats, but can also be found in large habitats (Stein et al. 2007).

Cux. imitator, Cux. davisi and Wy. muehlensi breed almost exclusively in bromeliads, both in Argentina and in neighbouring countries (Correa \& Ramallo 1956, Forattini 1965a, b, Casal \& Garcia 1970, Belkin et al. 1971, Torales et al. 1972, Lourenço-de-Oliveira et al. 1986). The large ranges for water temperature and $\mathrm{pH}$ recorded in our study for the habitats of Cux. imitator would indicate less stringent ecological requirement for this species.
Toxorhynchites in the immature stages were found in natural habitats, most commonly represented by bromeliads, tree holes and bamboo internodes (Forattini 1965b), although they were also found in artificial containers, such as tin, tire and plastic containers (Lopes 1997, Hoyos et al. 2010). In Venezuela, Machado-Allison et al. (1986) classified species of Toxorhynchites and Wyeomyia genera as species with a broad niche, collected from bromeliads and araceae, but notably absent in tree holes and bamboo. Torales et al. (1972), studying bromeliads in Corrientes, collected specimens of Cux. imitator, Cux. davisi and Wy. muehlensi from A. distichantha and they recorded a $\mathrm{pH}$ range between 4.6-6.7, which is consistent with our results.

We found Psorophora species in habitats exposed to sunlight, with or without vegetation, which was consistent with the findings of Lourenço-de-Oliveira et al. (1986) in Brazil. Other authors have referred to shade and a lack of vegetation in the breeding habitats of Psorophora (Forattini 1965a, Campos et al. 1995, Almirón \& Brewer 1996). Psorophora ferox (Von Humbolt) was also found in mangroves and the backwaters of rivers (GarciaÁvila 1977) and Psorophora confinnis (Arribalzaga) was also collected from excavations in rock, concrete artificial containers, deep pools, rivers and tree holes (Forattini 1965b, Garcia-Avila 1977, Clark-Gil \& Darsie 1983).

Ochlerotatus scapularis (Rondoni) was found during other studies in natural pools with grass, exposed to sunlight and in temporary ditches (Garcia-Ávila 1977, Lourenço-de-Oliveira et al. 1986). In Brazil, Oc. scapularis has been found in a variety of temporary or semi-permanent larval habitats, subject to an alternating flooding and drying regime in the urban environment (Forattini 1965b). This species has also been found in artificial containers, such as tins and tire tracks, and in natural habitats such as the backwaters of streams (Lourenço-de-Oliveira et al. 1986, da Silva \& de Menezes 1996, Forattini et al. 1997). Cux. pilosus was collected in association with Oc. albifasciatus and Cux. maxi larvae from pools with grass or aquatic plants (GarciaÁvila 1977, Lourenço-de-Oliveira et al. 1986, Pires et al. 2009). In our study, we collected these species together, but the type of larval habitat where they were more frequently collected and the presence of aquatic vegetation allowed us to group them separately.

Cux. quinquefasciatus was collected from artificial containers, deep pools, and ditches, the last containing abundant decaying organic matter, in accordance with other authors' reports (Lourenço-de-Oliveira et al. 1986, Campos et al. 1993, Almirón \& Brewer 1996, Oria et al. 1999, 2002). Lourenço-de-Oliveira et al. (1986) collected a specimen in a natural rock excavation. Cux. quinquefasciatus has also been found colonising the same artificial locations as Ae. aegypti in urban environments, although the biology of both species is quite different (Schweigmann et al. 1997, Almirón \& Ludueña-Almeida 1998, Stein \& Oria 2002, Stein et al. 2002).

The same situation can occur with the nucleus formed by Oc. albifasciatus and Cux. bidens, species with different biological characteristics. They share many habitat characteristics, both species being abundant in ditches. Cux. bidens has also been found in tires 
(Stein et al. 2007) and in metal containers (Almirón \& Brewer 1996, Stein \& Oria 2002). Almirón and Brewer (1996) found Oc. albifasciatus in association with Culex saltanensis Dyar mainly in pools, but it was also found in a fountain in Cordoba. Culex chidesteri Dyar has been collected in a permanent channel with marginal emergent vegetation, partial shade, semi-permanent and permanent ponds, partially exposed to the sun, swamp and drinking places (Garcia-Ávila 1977, Clark-Gil \& Darsie 1983, Lourenço-de-Oliveira et al. 1986, Almirón \& Brewer 1996). The presence of vegetation seems to be an important feature in the breeding habitat of this species (Almirón \& Brewer 1996). Our findings are consistent with these data. According to Forattini (1965a), it can also be found in the absence of vegetation.

Uranotaenia lowii Theobald and Culex eduardoi Casal y Garcia were collected mainly from permanent ditches with aquatic vegetation and exposed to sunlight. Similar data were recorded by Almirón and Brewer (1996) in Cordoba. Garcia-Ávila (1977) found Ur. lowii in temporary pools, the backwaters of rivers and lagoons with Salvinia spp and algae. It has also been collected from tires in Argentina (Stein et al. 2007) and plastic containers in Brazil (Lourenço-de-Oliveira et al. 1986). Consistent with our study, Almirón and Brewer (1996) found Cux. maxi in a variety of breeding places, consisting mainly of temporary and permanent natural habitats, located in shade or sunlight, with aquatic plants. Cux. maxi has also been found in artificial containers, such as tires, swimming pools, concrete and metal containers (Campos et al. 1993, Almirón \& Brewer 1996, Stein \& Oria 2002, Stein et al. 2007). Moreover, the wide ranges of $\mathrm{pH}$ and water temperature from which Cux. maxi was collected suggest that this species has broad environmental requirements.

In our study, Anopheles albitarsis Arribalzaga was collected mainly from pools with grass and, in a smaller proportion, from a lagoon with aquatic vegetation. However, it can also be found in many other habitats, from estuarine water regressions, depressions formed by animal footprints, marshes, rice boxes, artificial ditches, ground depressions, cement artificial containers, pools and lagoon margins, stagnant and clean water, with plants, grasses and Lemnaceae, exposed to sunlight, with a water temperature range between $16-22^{\circ} \mathrm{C}$ and at $\mathrm{pH}$ 6.6 (Del Ponte 1943, Umana et al. 1959, Forattini 1962, Almirón \& Brewer 1996). Campos (1997) found An. albitarsis larvae in habitats with floating and rooted vegetation, sunlit places, and a $\mathrm{pH}$ range between 5.6-6.8. An. albitarsis was found breeding in water with a broad range of $\mathrm{pH}$ values (3.8-7.9) (Milward de Andrade 1957). The association of Anopheles species with aquatic plants is reported by several authors (Rejmankova et al. 1992, Lopes \& Lozovei 1995, Rubio-Palis et al. 2005, Brochero et al. 2006). They were collected from large lagoons, with organic matter, exposed to partial shade or sunlight, having a $\mathrm{pH}$ range of 6-6.5 and a mean water temperature of $24.1^{\circ} \mathrm{C}$ or $26.5^{\circ} \mathrm{C}$ (Rejmankova et al. 1992, Berti et al. 1993, Lopes \& Lozovei 1995, Rubio-Palis et al. 2005). Lopes and Lozovei (1995) found Anopheles triannulatus (Neiva y Pinto), An. albitarsis and Culex (Melanoconion) spp in lagoons with aquatic vegetation and sunlight and from rivers with slow-moving water and without aquatic vegetation. Rejmankova et al. (1992) found that breeding sites with Cyperaceae, Typha dominguensis and planktonic algae were very productive for species of the Anopheles genus and were moderately productive for the Pistia spp and Eichornia spp.

Ad. squamipennis and Mansonia spp have been found in lagoons with aquatic vegetation, receiving direct sunlight (Clark-Gil \& Darsie 1983, García et al. 1995, Lopes \& Lozovei 1995), consistent with our findings. Ur. pulcherrima and Uranotaenia apicalis Theobald were also collected from swamps with abundant aquatic vegetation in Panama (Galindo et al. 1954). Lopes and Lozovei (1995) also found Ur. pulcherrima in a lake covered with aquatic vegetation, exposed to sunlight, from a swamp with abundant grass, and from the border of a river with vegetation. In our study, it was also collected from temporary habitats. Culex intrincatus Brethes was found almost exclusively in pools with grass, while Cux. pilosus was found in pools or in lagoons with aquatic plants. According to Sirivanakarn (1982), most of the Culex (Mel.) species develop in natural pools but a few are exclusively from bromeliad axils. Melanoconion species can also be collected in artificial depressions in the soil, lakes, lagoons, river margins and channels, with Pistia sp. or other aquatic vegetation, deep shade or sunlight. Our findings are consistent with these observations.

Species classification based on similar habitat characteristics has a predictive value as it can relate the presence of one species in a breeding location to other species with similar environmental requirements. To improve the predictive power of species classification, a greater variety of habitats present in the studied area must be analysed. Environmental features of Culicidae habitats are useful data for field entomologists and are of epidemiological interest.

\section{REFERENCES}

Almirón WR, Brewer ME 1996. Classification of immature stage habitats of Culicidae (Diptera) collected in Córdoba, Argentina. Mem Inst Oswaldo Cruz 91: 1-9.

Almirón WR, Ludueña-Almeida F 1998. Aedes aegypti (Diptera: Culicidae) en Córdoba, Argentina. Rev Soc Entomol Argent 57: 27-28.

Augier LM 1998. Presencia de Aedes aegypti (Diptera: Culicidae) en Tucumán, Argentina. Rev Soc Entomol Argent 57: 66.

Belkin JN, Hogue ChL, Galindo P, Aitken THG, Schick RX, Powder WA 1967. Mosquito studies (Diptera: Culicidae). IIa. Methods for collections, rearing and preservation of mosquitoes. Contrib Amer Ent Inst 1: 21-78.

Belkin JN, Schick RX, Heinemann SJ 1971. Mosquito (Diptera: Culicidae) XXV. Studies mosquitoes originally described from Brazil. Contrib Amer Ent Inst 7: 66.

Berti J, Zimmerman R, Amarista J 1993. Spatial and temporal distribution of Anopheline larvae in two malarious areas in Sucre State, Venezuela. Mem Inst Oswaldo Cruz 88: 353-362.

Borda CE, Rea MFJ, Rosa JR, Mosqueda LA, Sario H 1999. Vector de la fiebre amarilla urbana y el dengue en la ciudad de Corrientes, Argentina. Reunión de Comunicaciones Científicas y Tecnológicas de la UNNE. Libro de comunicaciones 3: 127-129. 
Bram RA 1967. Classification of Culex subgenus Culex in the New World (Diptera: Culicidae). Proc US Nat Hist Mus 120: 1-122.

Brochero H, Pareja PX, Ortiz G, Olano VA 2006. Sitios de cría y actividad de picadura de especies de Anopheles en el municipio de Cimitarra, Santander, Colombia. Biomedica (Bogotá) 26: 269-277.

Bruniard ED 1978. El gran Chaco argentino: ensayo de interpretación geográfica. Rev Geogr 4: 259.

Cabrera AL 1994. Regiones fitogeográficas argentinas, Enciclopedia Argentina de agricultura y jardinería, tomo II, editorial Acme SACI, Buenos Aires, 85 pp.

Campos RE 1997. Comportamiento estacional de dos especies de Anopheles (Diptera: Culicidae) en la provincia de Buenos Aires, Argentina. Rev Soc Entomol Argent 56: 31-32.

Campos RE, Maciá A, García JJ 1993. Fluctuaciones estacionales de culícidos (Diptera) y sus enemigos naturales en zonas urbanas de los alrededores de La Plata, provincia de Buenos Aires. Neotropica 39: 55-66.

Campos RE, Maciá A, García JJ 1995. Variación estacional de las poblaciones de Psorophora (Diptera: Culicidae) y detección de sus parásitos y patógenos en la Provincia de Buenos Aires, Argentina. Acta Ent Chilena 19: 113-121.

Casal OH, Garcia M 1970. Los tipos de tres especies descriptas por Juana Petrocchi (Diptera: Culicidae). Physis 30: 11-12.

Christophers SR 1960. Aedes aegypti (L.), the yellow fever mosquito. Its life history, bionomics and structure, Cambridge University Press, New York, 739 pp.

Clark-Gil S, Darsie Jr RF 1983. The mosquitoes of Guatemala, their identification, distribution and bionomics, with keys to adult females and larvae in English and Spanish. Mosq Syst 15: 151-284.

Consoli RAGB, Lourenço-de-Oliveira R 1994. Principais mosquitos de importância sanitária no Brasil, Fiocruz, Rio de Janeiro, 228 pp.

Correa RR, Ramallo GR 1956. Revisão de Phoniomyia Theobald, 1903 (Diptera: Culicidae, Sabethini). Folia Clin Biol 25: 1-176.

Crisci JV, Lopez Armengol MF 1983. Introducción a la teoría y práctica de la taxonomía numérica, Serie de biología, Monografía 26, Programa regional de desarrollo científico y tecnológico/Secretaría General de la Organización de los Estados Americanos, Washington, $132 \mathrm{pp}$.

da Silva AM, de Menezes RM 1996. Encontro de Aedes scapularis (Diptera: Culicidae) em criadouro artificial em localidade da região Sul do Brasil. Rev Saude Publica 30: 103-104.

Darsie RF 1985. Mosquitoes of Argentina. Part I. Keys for identification of adult females and fourth stages larvae in English and Spanish (Diptera: Culicidae). Mosq Syst 17: 153-253.

Del Ponte E 1943. Estudios sobre el paludismo del litoral argentino. Rev Inst Bacteriol Buenos Aires 11: 469-509.

Forattini OP 1962. Entomología médica. Parte general, Diptera, Anophelini, vol. I, Faculdade de Higiene e Saúde Pública, São Paulo, 622 pp.

Forattini OP 1965a. Entomología médica. Culicini: Culex, Aedes, Psorophora, vol. II, Universidade São Paulo, São Paulo, 506 pp.

Forattini OP 1965b. Entomología médica. Culicini: Haemagogus, Mansonia, Culiseta. Sabethini. Toxorhynchitini. Arboviruses. Filariose bancroftiana. Genetica, vol. III, Universidade São Paulo, $416 \mathrm{pp}$.

Forattini OP, Kakitani I, Mureb Sallum MA 1997. Encontro de criadouros de Aedes scapularis (Diptera: Culicidae) em recipientes artificiais. Rev Saude Publica 31: 519-522.
Galindo P, Blanton FS, Peyton EL 1954. A revision of the Uranotaenia of Panama with notes on other American species of the genus (Diptera: Culicidae). Annals Entomol Soc Am 47: 107-177.

García JJ, Campos RE, Macia A 1995. Observaciones ecológicas sobre Mansonia indubitans y Mansonia titillans (Diptera: Culicidae) y sus enemigos naturales en Punta Lara, Argentina. Rev Soc Entomol Argent 54: 43-50.

Garcia-Ávila I 1977. Fauna cubana de mosquitos y sus criaderos típicos, Dirección de publicaciones de la Academia de Ciencias de Cuba, Havana, 108 pp.

Hoyos CB, Bangher D, Jara GA y Stein M 2010. Estados inmaduros de Culicidae (Diptera) colectados en la provincia de Formosa. VII Jornadas Regionales sobre mosquitos. FCEQYN-UNaM Misiones. Argentina, $34 \mathrm{pp}$.

InfoStat/Profesional 2002, Versión 1.1., Estadística y Diseño, Facultad de Ciencias Agrárias/Universidad Nacional de Córdoba, Córdoba. Available from: infostat.uncor.edu.

Lane J 1953. Neotropical Culicidae, 1st/2nd ed., Ind Graf Siqueira SA, São Paulo, 1112 pp.

Lestani EA, Stein M, Liotta DJ, Martínez HV, Tonón SA 2002. Estudio preliminar de diversidad de culicifauna en recipientes artificiales de la ciudad de Posadas, Argentina. Available from: www1. unne.edu.ar/cyt/2002/06-Biologicas/B-063.pdf.

Lopes J 1997. Ecologia de mosquitos (Diptera: Culicidae) em criadouros naturais e artificiais de área rural do norte do Estado do Paraná, Brasil. V. Coleta de larvas em recipientes artificiais instalados em mata ciliar. Rev Saude Publica 31: 370-377.

Lopes J, Lozovei AL 1995. Ecologia de mosquitos (Diptera: Culicidae) em criadouros naturais e artificiais de área rural do norte do Estado do Paraná, Brasil. I- Coletas ao longo do leito de ribeirão. Rev Saude Publica 29: 183-191.

Lourenço-de-Oliveira R, Heyden R, Fernandes da Silva T 1986. Alguns aspectos da ecologia dos mosquitos (Diptera: Culicidae) de uma área de planície (Granjas Calábria), em Jacarepaguá, Rio de Janeiro. V. Criadouros. Mem Inst Oswaldo Cruz 81: 265-271.

Machado-Allison CE, Barrera R, Delgado RL, Gómez-Cova C, Navarro JC 1986. Mosquitos (Diptera: Culicidae) de los Fitotelmata de Panaquire, Venezuela. Acta Biol Venez 12: 1-12.

Mangudo C, Aparicio JP, Gleiser RM 2010. Huecos de árboles como hábitat larval de Aedes aegypti en el arbolado público de la localidad de Aguaray, provincia de Salta, VII Jornadas Regionales sobre mosquitos, September 2-3, FCEQYN, Universidad Nacional de Misiones, Posadas, $37 \mathrm{pp}$.

Milward de Andrade R 1957. Dados comparativos de $\mathrm{pH}$ em biótopos de anofelinos, pesquisados no Distrito Federal, Brasil. Rev Bras Malariol D Trop 9: 333-336.

Mitchell CJ, Monath TP, Sabattini MS, Cropp CB, Daffner JF, Calisher CH, Jakob WL, Christensen HA 1985. Arbovirus investigations in Argentina, 1977-1980. II. Arthropod collections and virus isolations from Argentina mosquitoes. Am J Trop Med Hyg 34: 945-955.

Mitchell CJ, Monath TP, Sabattini MS, Daffner JF, Cropp CB, Calisher CH, Darsie RF Jr, Jakob WL 1987. Arbovirus isolations from mosquitoes collected during and after the 1982-1983 epizootic of western equine encephalitis in Argentina. Am J Trop Med Hyg 36: 107-113.

Olmedo RA, Stetson RE, Alvarenga LA 1991. Índice de infestación por Aedes (Steg.) aegypt L. 1762 en la ciudad de Posadas, R. Argentina. Libro de resúmenes del II Congreso Argentino de Entomología, I Seminario Latinoamericano de vectores urbanos y animales sinantrópicos, I Reunión Latinoamericana sobre Simúlidos, La Cumbre, Córdoba, 234 pp. 
Oria GI, Stein M, Gorodner JO 1999. Nuevos aportes en mosquitos (Diptera: Culicidae) de Resistencia, Chaco, Reunión de Comunicaciones Científicas y Tecnológicas de la UNNE, tomo VI, Ciencias Biológicas, Editorial Universitária de la Universidad Nacional del Nordeste, Corrientes, p. 31-34.

Oria GI, Stein M, Gorodner JO 2002. Mosquitos, sus criaderos y factores socioculturales de la población en el nordeste argentino. Actualizaciones en artropodología sanitaria argentina, Serie Enfermedades Transmisibles, Publicación monográfica 2, Buenos Aires, p. 167-172.

Pires DA, Laurito M, Almirón WR, Gleiser RM 2009. First record of Culex (Melanoconion) pilosus from Córdoba city, Argentina. J Am Mosq Control Assoc 25: 206-207.

Pisano MB, Ré VE, Díaz LA, Farías A, Stein M, Sanchez-Seco MP, Tenorio A, Almirón WR, Contigiani MS 2010. Enzootic activity of pixuna and Rio Negro viruses (Venezuelan equine encephalitis complex) in a neotropical region of Argentina. Vector Borne Zoonotic Dis 10: 199-201.

Rejmankova E, Savage HM, Rejmanek M, Roberts DR, ArredondoJimenez JI 1991. Multivariate-analysis of relationships between habitats, environmental factors and occurrence of anopheline mosquito larvae (Anopheles albimanus, A. pseudopunctipennis) in southern Chiapas, Mexico. J Applied Ecol 28: 827-841.

Rejmankova E, Savage HM, Rodriguez MH, Roberts DR, Rejmanek M 1992. Aquatic vegetation as a basis of classification of Anopheles albimanus Weideman (Diptera: Culicidae) larval habitats. Environ Entomol 21: 598-603.

Ronderos RA, Bachman AO 1962. A propósito del complejo Mansonia (Diptera: Culicidae). Rev Soc Entomol Argent 25: 43-51.

Rubio-Palis Y, Menare C, Quinto A, Magris M, Amarista M 2005. Caracterización de criaderos de anofelinos (Diptera: Culicidae) vectores de malaria del Alto Orinoco, Amazonas, Venezuela. Entomotropica 20: 29-38.

Schweigmann NJ, Vezzani D, Vera T, Gómez S, Fernández Campón F, Cevasco C, Freire G, Kuruc J, Ackermann G, Carbajo A, Bruzzone OA, Boffi R, Abramo Orrego L 1997. Infestación domiciliaria por formas inmaduras de Aedes (Stegomyia) aegypti L. En un foco del partido de San Martín, provincia de Buenos Aires, Argentina. Entomol Vectores 4: 185-190.

Sirivanakarn S 1982. A review of the systematics and a proposed scheme of internal classification of the new world subgenus Melanoconion of Culex (Diptera: Culicidae). Mosquito Systematics 14: 265-333.

Stein M, Almirón WR, Ludueña-Almeida F, Zapata L, Mari E, Gorodner JO 2007. Aedes aegypti y culícidos asociados (Diptera: Culicidae) en la ciudad de Corrientes, Argentina. Available from: www.siicsalud.com/dato/dat051/06d28002.htm.

Stein M, Oria GI 2002. Identificación de criaderos de Aedes aegypti (Diptera: Culicidae) y cálculo de índices de infestación en la provincia del Chaco. In OD Solomón, Actualizaciones en artropodología sanitaria Argentina, Publicación Monográfica 2, Buenos Aires, p. 161-166.

Stein M, Oria GI, Almirón WR 2002. Principales criaderos para Aedes aegypti y culícidos asociados, Argentina. Rev Saude Publica 36: 627-630.

Torales GJ, Hack WH, Turn B 1972. Criaderos de culícidos en bromeliáceas del NW de Corrientes. Acta Zoologica Lilloana 29: 293-308.

Umana AC, Heredia RL, Siquot JC 1959. Estudios sobre el Anopheles (N.) albitarsis en la Argentina, Primeras Jornadas Entomoepidemiológicas Argentinas, 5th session, Dirección General de Sanidad de la Secretaría de Guerra, Buenos Aires, p. 609-618. 
TABLE

Number of mosquito species collected by larval habitat, size, grass, substratum and water characteristics in immature stages habitats sampled in the province of Chaco, Argentina

\begin{tabular}{|c|c|c|c|c|c|c|c|c|c|c|c|c|c|c|c|c|}
\hline \multirow[b]{2}{*}{ Group } & \multirow[b]{2}{*}{ Species } & \multicolumn{10}{|c|}{ Larval habitat } & \multicolumn{5}{|c|}{ Water } \\
\hline & & $\begin{array}{r}\text { Brom } \\
\text { Terrestrial }\end{array}$ & $\begin{array}{l}\text { eliad } \\
\text { Epiphytic }\end{array}$ & Lagoon & Pool & Ditch & $\begin{array}{l}\text { Deep } \\
\text { pool }\end{array}$ & $\begin{array}{l}\text { Artificial } \\
\text { container }\end{array}$ & $\begin{array}{r}\text { Size } \\
(\mathrm{m})\end{array}$ & Grass & Substrate & $\begin{array}{l}\text { Temperature } \\
{ }^{\circ} \mathrm{C} \text { (mean) }\end{array}$ & Colour & $\mathrm{pH}$ (mean) & Permanence & Depth \\
\hline 1 & Aedes aegypti & - & - & - & - & - & - & 466 & $0.5-0.65 \times 0.65-1.5$ & A & - & 19-37 (29.75) & $\mathrm{B} / \mathrm{R}$ & 7.6-8.12 (7.93) & TE & $0.01-0.03$ \\
\hline \multirow[t]{4}{*}{2} & Culex imitator & 2,281 & 206 & - & - & - & - & - & $0.9-1.5$ & A & - & $6-39(25.76)$ & $\mathrm{T} / \mathrm{Y} / \mathrm{R}$ & $4-8.50(6.24)$ & $\mathrm{P}$ & $0.01-0.25$ \\
\hline & Wyeomyia muehlensi & 214 & 9 & - & - & - & - & - & $1.2-1.5$ & A & - & $6-32(23.56)$ & $\mathrm{T} / \mathrm{Y} / \mathrm{R}$ & $4-8.5(5.98)$ & $\mathrm{P}$ & $0.01-0.15$ \\
\hline & Toxorhynchites haemorroidalis separatus & 74 & 6 & - & - & - & - & - & $0.9-1.5$ & A & - & $16-39(25.21)$ & $\mathrm{T} / \mathrm{Y} / \mathrm{R}$ & $4-7.4(5.83)$ & $\mathrm{P}$ & $0.02-0.08$ \\
\hline & Culex davisi & 49 & 9 & - & - & - & - & - & $0.9-1.5$ & A & - & 6-33 (24.90) & $\mathrm{T} / \mathrm{Y} / \mathrm{R}$ & $4-7.0(6.02)$ & $\mathrm{P}$ & $0.01-0.06$ \\
\hline \multirow[t]{14}{*}{$3 \mathrm{~A}$} & Psorophora ciliata & - & - & - & 113 & 6 & 1 & - & $0.1-3 \times 0.15-50$ & $\mathrm{PR} / \mathrm{A}$ & M & $20-38(27.67)$ & B & $6-8.1(6.60)$ & $\mathrm{TE} / \mathrm{SP}$ & $0.01-0.23$ \\
\hline & Psorophora varinervis & - & - & - & 330 & - & - & - & $0.15-7 \times 0.15-35$ & $\mathrm{PR} / \mathrm{A}$ & M & $22-40(31.16)$ & B & $6-8.28(7.36)$ & $\mathrm{TE} / \mathrm{SP}$ & $0.05-0.35$ \\
\hline & Psorophora confinnis & - & - & - & 460 & 1 & 32 & - & $0.08-5 \times 0.09-35$ & $\mathrm{PR} / \mathrm{A}$ & M & $7-40(29.46)$ & B & $6-8.83(7.30)$ & $\mathrm{TE} / \mathrm{SP}$ & $0.01-0.64$ \\
\hline & Psorophora cyanescens & - & - & - & 377 & 15 & 8 & - & $0.1-8 \times 0.15-35$ & $\mathrm{PR} / \mathrm{A}$ & M & $20-35(28.25)$ & $\mathrm{T} / \mathrm{B}$ & 6-8.44 (6.95) & $\mathrm{TE} / \mathrm{SP}$ & $0.04-0.23$ \\
\hline & Psorophora cingulata & - & - & - & 491 & 9 & 86 & - & $0.15-50$ & $\mathrm{PR} / \mathrm{A}$ & M & $7-40(27.31)$ & $\mathrm{T} / \mathrm{B}$ & $6-8.58(7.40)$ & $\mathrm{TE} / \mathrm{SP}$ & $0.02-0.27$ \\
\hline & Psorophora ferox & - & - & - & 364 & - & - & - & $0.1-8 \times 0.12-35$ & PR & M & $10-34(25.54)$ & B & $5-8.11(7.14)$ & $\mathrm{TE} / \mathrm{SP}$ & $0.01-0.25$ \\
\hline & Ochlerotatus hastatus/oligopistus & - & - & - & 875 & - & - & - & $0.1-4.5 \times 0.1-50$ & $\mathrm{PR} / \mathrm{A}$ & M & $10-35(24.47)$ & $\mathrm{T} / \mathrm{B}$ & $6-8.28(7.02)$ & TE/SP & $0.03-0.27$ \\
\hline & Ochlerotatus serratus & - & - & - & 635 & 5 & 41 & - & $0.12-5 \times 0.12-30$ & $\mathrm{PR} / \mathrm{A}$ & M & $9-34(24.6)$ & $\mathrm{T} / \mathrm{B}$ & $6-8.21(7.15)$ & TE/SP & $0.04-0.20$ \\
\hline & Ochlerotatus scapularis & - & - & - & 578 & 68 & 4 & - & $0.12-10 \times 0.12-30$ & $\mathrm{PR} / \mathrm{A}$ & $\mathrm{M} / \mathrm{S}$ & $7-32(22,2)$ & $\mathrm{T} / \mathrm{B}$ & $6-8,58(7,11)$ & TE/SP & $0.02-0.27$ \\
\hline & Culex intrincatus & - & - & 3 & 82 & 2 & - & - & $0.10-4$ x $0.1-25$ & $\mathrm{PR} / \mathrm{A}$ & M & 15-34 (23.33) & $\mathrm{B}$ & $5-8.60(7.34)$ & TE/SP/P & $0.04-0.25$ \\
\hline & Culex quinquefasciatus & - & - & - & 11 & 208 & 1,350 & 71 & $0.2-10 \times 0.9-30$ & PR & M & $9-33(23.12)$ & $\mathrm{B}$ & $6-8.50(8.23)$ & TE/SP/P & $0.02-0.18$ \\
\hline & Culex pilosus & - & - & 12 & 334 & 6 & 3 & - & $0.15-10 \times 0.15-30$ & $\mathrm{PR} / \mathrm{A}$ & $\mathrm{M}$ & $14-35(25.91)$ & $\mathrm{T} / \mathrm{B}$ & $5-8.58(7.07)$ & TE/SP/P & $0.02-0.25$ \\
\hline & Ochlerotatus albifasciatus & - & - & - & 185 & 89 & - & - & $0.2-10 \times 0.25-30$ & $\mathrm{PR} / \mathrm{A}$ & $\mathrm{M} / \mathrm{S}$ & $12-32(21.32)$ & $\mathrm{T} / \mathrm{B}$ & $6-8.30(7.19)$ & TE/SP & $0.02-0.25$ \\
\hline & Culex bidens & - & - & 27 & 158 & 248 & 4 & - & $0.3-10 \times 0.1-50$ & PR & $\mathrm{M} / \mathrm{S}$ & 7-38 (22.99) & $\mathrm{T} / \mathrm{B}$ & $5-8.67(7.26)$ & $\mathrm{TE} / \mathrm{SP} / \mathrm{P}$ & $0.03-0.28$ \\
\hline \multirow[t]{11}{*}{ 3B } & Culex maxi & - & - & 241 & 1,343 & 759 & 261 & - & $0.1-10 \times 0.1-40$ & $\mathrm{PR} / \mathrm{A}$ & $\mathrm{M} / \mathrm{S}$ & $7-40(23.48)$ & $\mathrm{T} / \mathrm{B}$ & $5-8.74(6.80)$ & TE/SP/P & $0.01-0.28$ \\
\hline & Uranotaenia lowii & - & - & 65 & 91 & 317 & - & - & $0.1-10 \times 0.1-50$ & PR & $\mathrm{S}$ & $9-36(21.72)$ & $\mathrm{T} / \mathrm{B}$ & $6-8.61(7.45)$ & $\mathrm{TE} / \mathrm{SP} / \mathrm{P}$ & $0.02-0.27$ \\
\hline & Culex eduardoi & - & - & 34 & 49 & 190 & - & - & $0.1-15 \times 0.1-35$ & PR & $\mathrm{S}$ & 7-34 (19.07) & $\mathrm{T} / \mathrm{B}$ & $6-8.28(7.27)$ & $\mathrm{SP} / \mathrm{P}$ & $0.04-0.80$ \\
\hline & Culex chidesteri & - & - & 37 & 22 & 22 & 2 & - & $0.1-15 \times 0.1-50$ & PR & $\mathrm{M} / \mathrm{S}$ & $12-34(22.32)$ & $\mathrm{T} / \mathrm{B}$ & $6-8.98(7.45)$ & $\mathrm{SP} / \mathrm{P}$ & $0.04-0.28$ \\
\hline & Anopheles neomaculipalpus & - & - & 9 & 85 & - & - & - & $0.1-8 \times 0.1-50$ & $\mathrm{PR} / \mathrm{A}$ & M & $9-39(25.50)$ & $\mathrm{B}$ & $5-8.15(7.02)$ & $\mathrm{TE} / \mathrm{P}$ & $0.02-0.10$ \\
\hline & Uranotaenia pulcherrima & - & - & 18 & 17 & - & - & - & $0.10-5 \times 0.10-50$ & PR & $\mathrm{M} / \mathrm{S}$ & $8-32(25.06)$ & $\mathrm{B}$ & $6-8.43(6.89)$ & $\mathrm{TE} / \mathrm{P}$ & $0.03-0.25$ \\
\hline & Anopheles triannulatus & - & - & 218 & 110 & 7 & - & - & $0.10-6 \times 0.10-50$ & PR & $\mathrm{M} / \mathrm{S}$ & $8-40(24.11)$ & $\mathrm{T} / \mathrm{B}$ & $6-8.77(7.31)$ & TE/SP/P & $0.05-0.37$ \\
\hline & Anopheles albitarsis & - & - & 69 & 129 & 4 & - & - & $0.10-6 \times 0.10-50$ & $\mathrm{PR} / \mathrm{A}$ & $\mathrm{M} / \mathrm{S}$ & $7-39(23.52)$ & $\mathrm{T} / \mathrm{B}$ & $6-8.98(7.19)$ & $\mathrm{TE} / \mathrm{SP} / \mathrm{P}$ & $0.10-0.35$ \\
\hline & Uranotaenia apicalis & - & - & 86 & 2 & 3 & 1 & - & $0.10-5 \times 0.10-50$ & PR & $\mathrm{S}$ & $20-36(28.65)$ & $\mathrm{B}$ & $6-8.22(7.37)$ & $\mathrm{SP} / \mathrm{P}$ & $0.03-0.27$ \\
\hline & Mansonia humeralis & - & - & 59 & - & - & - & - & $3.88-4 \times 30-50$ & $\mathrm{~A}$ & S & $15-40(27.38)$ & B & $5-7.80(7.21)$ & $\mathrm{P}$ & $0.09-0.32$ \\
\hline & Aedeomyia squamipennis & - & - & 105 & - & - & - & - & $3.88-4$ x 30-50 & A & S & $18-40(28.25)$ & $\mathrm{B}$ & 6-7.97 (7.32) & $\mathrm{P}$ & $0.09-0.30$ \\
\hline
\end{tabular}

A: absence; B: brown; M: muddy; P: permanent; PR: presence; R: reddish; S: sandy; SP: semi-permanent; T: transparent; TE: temporary; Y: yellowish. 